\title{
Effect of restricted nutrition on timing of puberty in female Soay sheep
}

\author{
C. L. Adam, P. A. Findlay, C. E. Kyle and P. Young \\ Molecular Neuroendocrinology Unit, Rowett Research Institute, Bucksburn, Aberdeen AB21 9SB, UK
}

\begin{abstract}
Ovariectomized, oestradiol-implanted Soay ewe lambs from 21 September (aged 21 weeks) had restricted (liveweight maintenance) $(n=4)$ or unrestricted food $(n=4)$; ovary-intact lambs had unrestricted food $(n=8)$. LH activation in ovariectomized lambs on restricted and unrestricted food and onset of ovulatory cycles in ovary-intact lambs all occurred on 7 December (SED 8.8 days) (32 weeks), but at different liveweights $(24.2,17.9$ and $18.3 \mathrm{~kg}$, respectively, SED 1.22). LH pulse frequency was similar in ovariectomized lambs on restricted and unrestricted food. From 29 August (aged 18 weeks), Soay ewe lambs in seasonally advanced decreased artificial daylength were given restricted food, unrestricted food, or food was restricted for 8 weeks and then unrestricted ( $n=8$ per group). Ovarian cycles started 3 weeks earlier than in lambs in natural photoperiod on similar dates for all three groups (14, 18 and 19 November, respectively, SED 5.5 days) (29 weeks), but at different liveweights $(16.2,20.7$, and $18.4 \mathrm{~kg}$, respectively, SED 0.87). From I August, Suffolk $\times$ Greyface ewe lambs (aged 16 weeks) had restricted food, unrestricted food, or food restricted for 8 weeks and then unrestricted ( $n=8$ per group). By 1 November (29 weeks), 0/8 lambs on restricted food $(29.3 \pm 0.92 \mathrm{~kg}$ ) but $8 / 8$ lambs on unrestricted food and 5/8 lambs on 8 weeks of restricted food had ovulated (mean dates: 16 October \pm 2.5 days (27 weeks, $40.1 \pm 1.02 \mathrm{~kg}$ ), and I November \pm 3.0 days ( 29 weeks, $35.5 \pm 1.23 \mathrm{~kg}$ ), respectively. Thus, nutritional growth restriction during the 11 weeks preceding normal puberty delayed pubertal date in the improved breed but did not influence the timing of puberty in the unimproved Soay breed within the weight range studied.
\end{abstract}

\section{Introduction}

The pronounced seasonal reproductive biology of adult Soay rams is well documented and artificial lighting experiments have demonstrated the profound photosensitivity of this unimproved breed (Lincoln and Short, 1980). However, the seasonal endocrinology of Soay ewes and ewe lambs is not well documented. The lambs are born in late spring and can attain puberty during the short days of the subsequent autumn (Lincoln and Baker, 1995). However, it is not known to what extent bodyweight modifies the timing of pubertal reproductive development in Soay ewe lambs as it does in improved commercial sheep breeds (Foster et al., 1985). Above a threshold below which puberty does not occur, low bodyweight in commercial ewe lambs is associated with delayed puberty during the first breeding season (Suttie et al., 1991). Moreover, severe chronic nutritional growth restriction inhibits activation of the $\mathrm{GnRH}$ pulse generator, thereby preventing overt puberty (Foster et al., 1989), and inhibited animals respond rapidly to an improvement in nutritional status with increased LH secretion and overt puberty (Foster et al., 1989; Suttie et al., 1991). It is not known whether ewe lambs of the highly photosensitive Soay breed show similar responses to nutritional alterations. Accurate measurement of GnRH activation in ewe lambs is

Revised manuscript received 4 June 1997. facilitated after ovariectomy and replacement with a constant concentration of gonadal steroid via a subcutaneous oestradiolcontaining implant: a marked increase in LH output (neuroendocrine puberty) occurs at around the same time as the first ovulations (overt puberty) in ovary-intact contemporaries (Foster and Olster, 1985).

The objective of the present study was to determine the effects of food intake and bodyweight on the timing of puberty in ewe lambs of the unimproved Soay breed. The aim of the first experiment was to investigate in natural photoperiod the effect of low versus high planes of rearing nutrition on the timing of the pubertal rise in LH secretion in ovariectomized, oestradiol-implanted Soay ewe lambs, and to compare this with the timing of first ovulation in ovary-intact Soay ewe lambs. The results of the first experiment revealed no significant influence of bodyweight or food intake on the timing of puberty, suggesting that the ultimate limiting factor was the time of year (that is, the photoperiod) rather than nutrition. Therefore, the second experiment aimed to advance the attainment of permissive photoperiod in an attempt to allow nutrition to be the final limiting factor. Soay ewe lambs were exposed to an advanced seasonal decline in artificial daylength, during which the effects of contrasting nutritional regimens on the timing of first ovulation were examined. A third experiment was included to compare the pubertal responses with similar nutritional regimens shown by ewe lambs of improved commercial breeding (Suffolk $\times$ Greyface). 

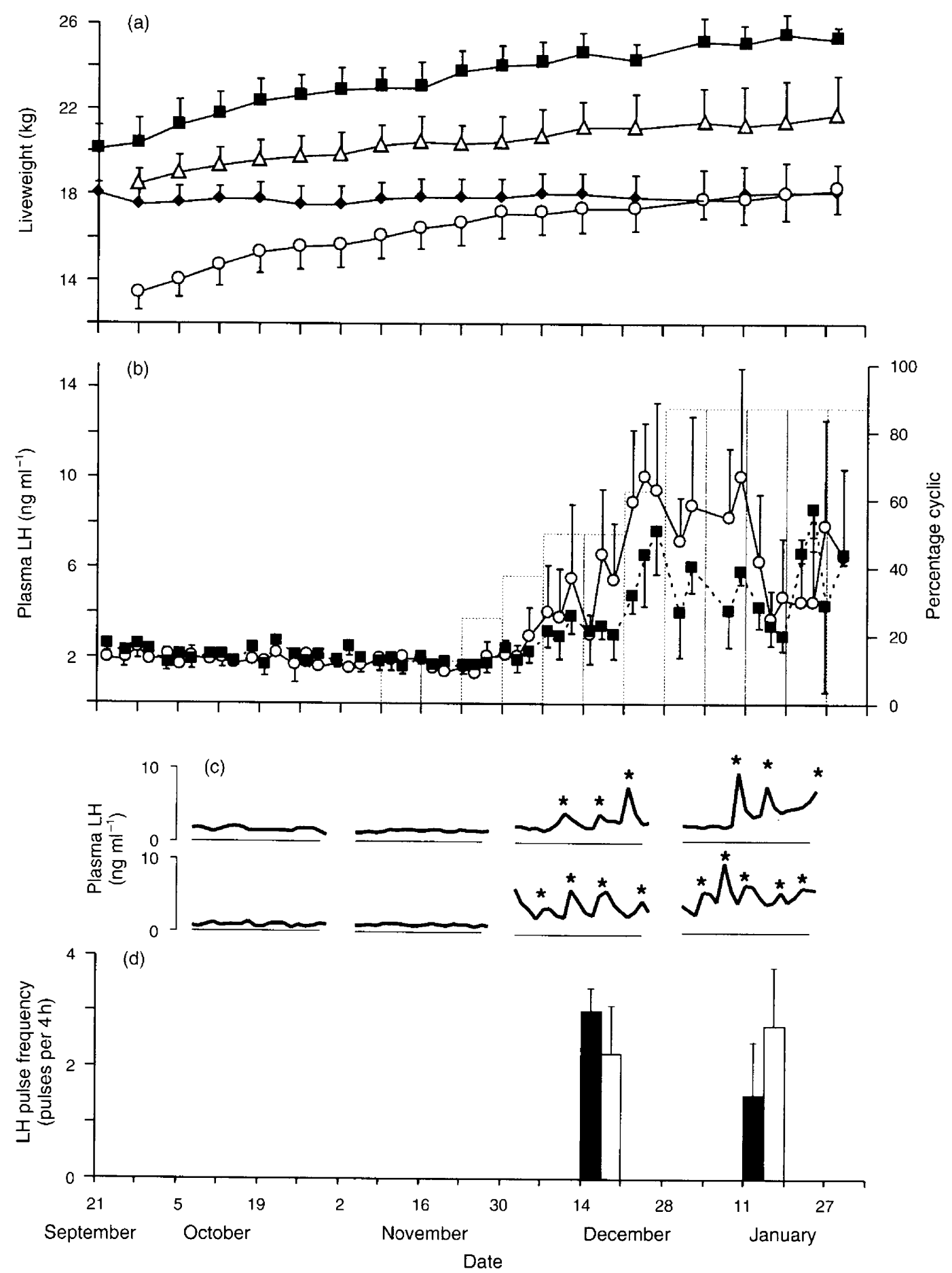

Fig. 1. (a) Mean liveweights of ovariectomized Soay ewe lambs on restricted ( $\bullet$ OVXR) or ad libitum ( $\boldsymbol{\square}$; OVXF) food intake, and of ovary-intact counterparts on ad libitum intake (OVIF) with low $(O)$ or high $(\triangle)$ starting liveweight. (b) Mean plasma LH concentrations in OVXR $(O)$ and OVXF ( $\boldsymbol{\square}$ ) groups, and percentage of OVIF lambs showing ovarian cyclicity (shaded area). (c) Individual plasma LH profiles over $4 \mathrm{~h}$ in October, November, December and January for example OVXR (top) and OVXF lambs (lower) (asterisks denote significant pulses). (d) Mean LH pulse frequency in OVXR ( $\boldsymbol{\square}$ ) and OVXF ( $\square$ ) groups (Expt 1). 


\section{Materials and Methods}

\section{Animals and treatments}

All experiments complied with the Animals (Scientific Procedures) Act 1986.

Experiment 1. Sixteen Soay ewe lambs (birth dates 17-30 April 1994) from the Duthie Farm flock (Rowett Research Institute) were weaned in August (liveweight range 11.5$19.5 \mathrm{~kg}$ ). Eight were ovariectomized under general inhalational anaesthesia induced by Halothane (Rhone Merieux Ltd, Harlow) and nitrous oxide (BOC Ltd, Aberdeen) supplied by a calibrated anaesthetic machine. At the same time they were each given a subcutaneous implant made from Silastic tubing (external diameter, $4.8 \mathrm{~mm}$; internal diameter, $3.2 \mathrm{~mm}$; Osteotec Ltd, Christchurch, Dorset) and containing a $15 \mathrm{~mm}$ packed column of oestradiol (Sigma International, Poole), designed to produce physiological prepubertal plasma oestradiol concentrations of 2-4 $\mathrm{pg} \mathrm{ml}^{-1}$ (Karsch et al., 1973; Foster and Ryan, 1979). Eight lambs remained ovary-intact. All lambs were penned in within-treatment pairs in natural photoperiod $\left(57^{\circ} \mathrm{N}\right)$ and offered a diet comprising $50 \%$ hay, $30 \%$ barley and $9 \%$ white fish meal, molasses, minerals and vitamins (containing $10 \mathrm{MJ}$ metabolizable energy and $140 \mathrm{~g}$ crude protein $\mathrm{kg}^{-1}$ dry weight) ad libitum until the start of the trial. For 18 weeks from 21 weeks of age on 21 September, four ovariectomized lambs had their daily food intake restricted to $0.35 \mathrm{~kg}$ dry weight per head not only to prevent weight gain but to maintain liveweight (maintenance) (OVXR), and four ovariectomized lambs were fed ad libitum (approximately twice maintenance amounts) for high weight gain (OVXF). The eight ovary-intact ewe lambs were all fed ad libitum (OVIF) over the same period and comprised two subgroups of high and low initial liveweight ( $n=4$ per subgroup). Blood samples were taken three times per week by jugular venepuncture for LH (Groups OVXF and OVXR) or progesterone (Group OVIF) analysis, and for $4 \mathrm{~h}$ at 12 min intervals via a jugular catheter on one occasion during each month from October to January for LH determinations (Groups OVXR and OVXF). Liveweight was recorded each week.

Experiment 2. Twenty-four Soay ewe lambs (birth dates 17-30 April 1995) from the Duthie Farm flock were weaned on 1 August (liveweight range $10.0-17.5 \mathrm{~kg}$ ). They were penned individually in light-sealed rooms and given an artificial light control regimen designed to photostimulate seasonally advanced puberty. A daylength was provided which decreased from $18 \mathrm{~h}$ light per $24 \mathrm{~h}$ by $1 \mathrm{~h}$ per week for 10 weeks, and remained at $8 \mathrm{~h}$ light per $24 \mathrm{~h}$ from 9 October onwards. The photoperiod-advanced lambs were given the same diet as in Expt 1 ad libitum until the imposition of the following regimens for 16 weeks from 18 weeks of age on 29 August $(n=8$ per group): restricted to prevent growth but to maintain liveweight (maintenance) $\left(0.35 \mathrm{~kg}\right.$ dry matter per head day ${ }^{-1}$ ) (PR), ad libitum (1.6-2.0 $\times$ maintenance) (PF), or restricted for 8 weeks and then fed ad libitum (PR/F). Liveweight was recorded each week and blood samples were taken by jugular venepuncture three times per week for progesterone analysis.
Experiment 3. Twenty-four Suffolk $\times$ Greyface ewe lambs (birth dates 1-14 April 1996) from the Duthie Farm flock were weaned on 12 July (liveweight range $26.0-36.0 \mathrm{~kg}$ ). They were individually penned in natural photoperiod and given the same diet as in Expts 1 and 2 ad libitum until the imposition of the following regimens at 16 weeks of age on I August $(n=8$ per group): restricted to prevent growth but to maintain liveweight (maintenance) $\left(0.50 \mathrm{~kg}\right.$ dry matter per head day $\left.{ }^{-1}\right)(\mathrm{CR})$, ad libitum (approximately twice maintenance intake) $(\mathrm{CF})$, or restricted for 8 weeks and then fed ad libitum (CR/F). Liveweight was recorded each week and blood samples were taken by jugular venepuncture three times per week for progesterone analysis. Under the Animals (Scientific Procedures) Act 1986, Group $\mathrm{CR}$ had undergone the maximum growth restriction allowed and were killed on 1 November (aged 29 weeks) by lethal injection of sodium pentobarbitone (Euthesate, Willows Francis Veterinary, Crawley); their ovaries were examined for follicles and for corpora lutea as evidence of ovulation. The other groups continued on their treatments until 8 November ( $n=4$ CF lambs), or 13 December (all CR/F and remaining CF lambs).

\section{Radioimmunoassays}

Progesterone was measured in extracted plasma samples by the method of Djahanbahkch et al. (1981). Inter- and intra-assay coefficients of variation $(\mathrm{CVs})$ averaged, respectively, $7.6 \%$ and $9.1 \%$ at $0.4-3.9 \mathrm{ng} \mathrm{ml}^{-1}$, and the detection limit of the assay was $0.025 \mathrm{ng} \mathrm{ml}^{-1}$.

LH was measured as described by Adam et al. (1994). Parallelism was demonstrated between serial dilutions of Soay plasma and the bovine LH standard (UCB Bioproducts, Shield Diagnostics Ltd, The Technology Park, Dundee) which had been calibrated against the First International Standard (EHCbLH-1) (Loeber et al., 1987). Inter- and intra-assay CVs averaged $6.9 \%$ and $7.0 \%$, respectively, at $1.6-8.9 \mathrm{ng} \mathrm{ml}^{-1}$, and the assay sensitivity was $0.25 \mathrm{ng} \mathrm{ml}^{-1}$.

Oestradiol was measured in extracted plasma samples from the ovariectomized, oestradiol-implanted lambs on two dates (October and December) by the method of Mann et al. (1995) in one assay run. The intra-assay CV was $8.9 \%$ at $2.3 \mathrm{pg} \mathrm{ml}^{-1}$, and the detection limit was $0.4 \mathrm{pg} \mathrm{ml}^{-1}$.

\section{Statistical analysis}

Puberty was defined for ovariectomized lambs by the starting point of a sustained increase in circulating LH concentrations and, for ovary-intact lambs, by the start of cyclical increases in plasma progesterone values above $1 \mathrm{ng} \mathrm{ml}^{-1}$ for at least four successive samples or, in Expt 3, by an increase in plasma progesterone accompanied by detection of a corpus luteum post mortem. Thus, a pubertal date was obtained for each individual. Linear correlation was used to examine the relationship between pubertal date and liveweight for the Soays (not for the Suffolk-cross lambs since one group did not reach puberty). The LH pulse frequency was obtained for each ovariectomized lamb during the $4 \mathrm{~h}$ frequent sampling periods 
using PulseFit software (University of Michigan). Group means are presented \pm SEM and compared using Student's $t$ test.

\section{Results}

\section{Experiment 1}

Plasma oestradiol averaged $2.6 \pm 0.53 \mathrm{pg} \mathrm{ml}^{-1}$ in ovariectomized lambs in October and December. OVXR lambs maintained constant liveweight, whereas OVXF and OVIF lambs grew steadily throughout (Fig. Ia). The pubertal increase in circulating $\mathrm{LH}$ concentrations in Groups OVXF (in $8 / 8$ individuals) and OVXR (8/8), and the onset of ovarian cyclicity in Group OVIF (7/8), all occurred on the same mean calendar date of 7 December \pm 5.0 , \pm 6.2 , and \pm 7.2 days, respectively (Fig. Ib), at 32 weeks of age, but at different mean liveweights of $24.2 \pm 0.85,17.9 \pm 0.87(P<0.001$ ), and $18.3 \pm 0.99$ (subgroups $19.8 \pm 1.30(P<0.05)$ and $17.1 \pm 1.23(P<0.001)) \mathrm{kg}$, respectively ( $P$ values represent differences from OVXF group). No LH pulses were detected in OVXF and OVXR lambs in October and November, and similar pulse frequencies were observed in both groups in December and January (Fig. Id). There was no correlation between bodyweight (range 14.0$26.0 \mathrm{~kg}$ ) and date of puberty for all 15 lambs (Fig. 2a). One lamb did not attain puberty despite weighing $22 \mathrm{~kg}$ on the mean pubertal date for its group (OVIF); it was unclear whether this was attributable to a genuine delay in first ovulation or to an ovarian defect.

\section{Experiment 2}

Contrasting patterns of liveweight gain were shown between the groups (Fig. 3). Compared with Expt 1, ovarian activity was initiated 3 weeks earlier in these photoperiodadvanced lambs $(P<0.001)$. The mean onset occurred on similar dates for Groups PF (7/8), PR (8/8) and PF/R (8/8) of $18 \pm 5.0,14 \pm 3.0$, and $19 \pm 2.2$ November (date \pm days), respectively (Fig. 3), at about 29 weeks of age, but at different liveweights of $20.7 \pm 0.41,16.2 \pm 0.77(P<0.001)$ and $18.4 \pm 0.79(P<0.05) \mathrm{kg}$, respectively $(P$ values represent differences from $\mathrm{PF}$ group). There was no correlation between liveweight (range $13.0-22.5 \mathrm{~kg}$ ) and date of onset of ovarian cyclicity for all 23 lambs, and there was no effect of food intake (Fig. 2b). One lamb did not show any increase in plasma progesterone during the trial despite weighing $21 \mathrm{~kg}$ on the mean pubertal date for its group (PF); it was not clear whether this failure to attain puberty was attributable to a delay in first ovulation or to an ovarian defect.

\section{Experiment 3}

Contrasting patterns of liveweight gain were shown between the groups (Fig. 4). On I November, at 29 weeks of age, none of the eight CR lambs had ovulated (liveweight $29.3 \pm 0.92 \mathrm{~kg}$, range $26.5-33.5 \mathrm{~kg}$ ), although small-mediumsized follicles were present on all ovaries. However, by 1 November, $8 / 8 \mathrm{CF}$ and 5/8 CR/F lambs had ovulated, initiating ovarian cyclicity on mean dates of 16 October \pm 2.5 days

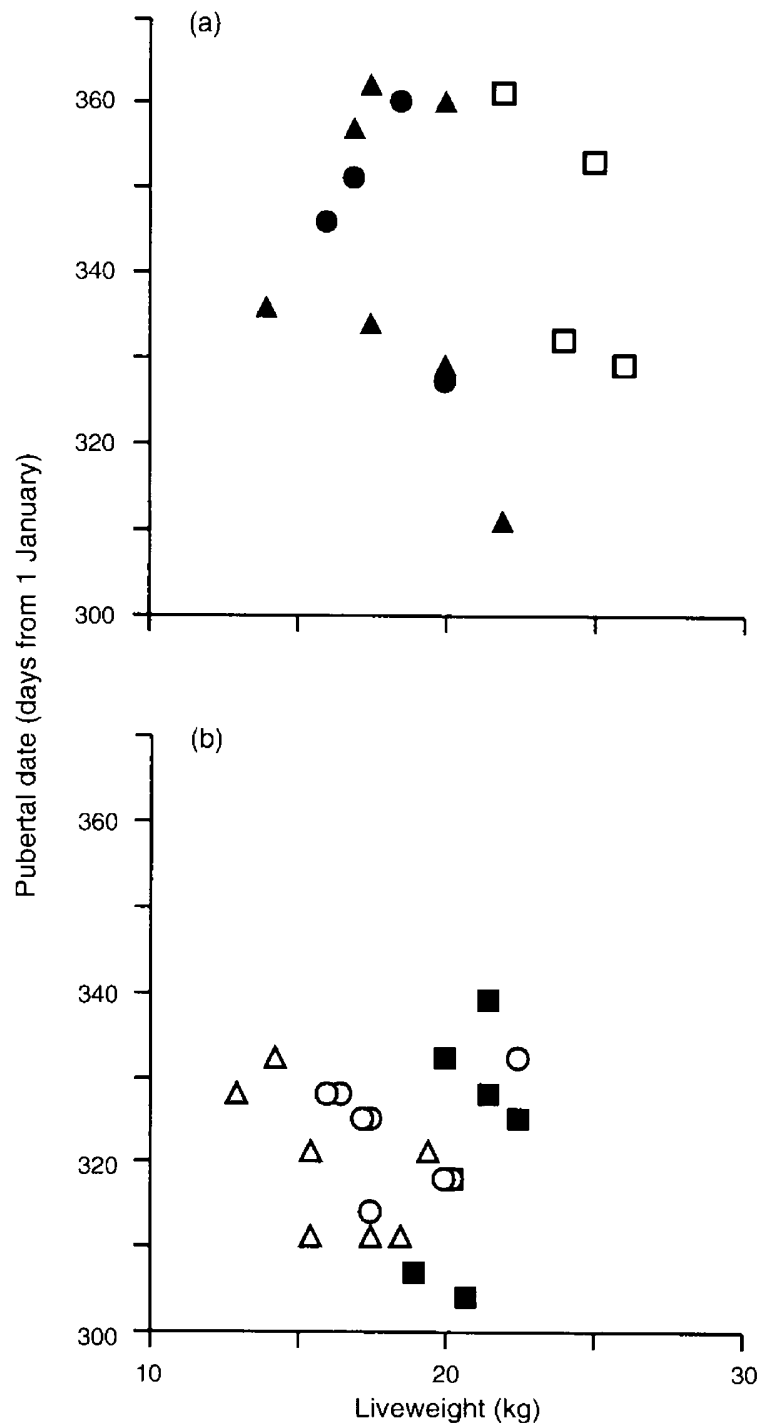

Fig. 2. Relationship between date of puberty and liveweight for Soay ewe lambs (a) ovariectomized and given restricted ( OVXR) or ad libitum ( $\square$; OVXF) food intake, and ovary-intact Soay ewe lambs on ad libitum intake ( $\boldsymbol{\Delta}$; OVIF) $\left(r^{2}=0.061\right.$; Expt 1), in natural photoperiod, and (b) reared in an artificial photoperiod regimen providing a seasonally advanced decrease in daylength and given restricted food intake $(\triangle ; P R)$, ad libitum food intake $(\mathbf{\square} ; \mathrm{PF})$, or restricted followed by ad libitum intake $(O ; P R / F)\left(r^{2}=0.006\right.$; Expt 2).

(aged 27 weeks) and I November \pm 3.0 days (aged 29 weeks) $(P<0.005)$, respectively, at mean liveweights of $40.1 \pm 1.02 \mathrm{~kg}$ (range $35.0-44.5 \mathrm{~kg}$ ) and $35.5 \pm 1.23 \mathrm{~kg}$ (range $31.0-42.0 \mathrm{~kg}$ ), respectively $(P<0.01)$.

\section{Discussion}

The results of the present study demonstrated a relative lack of influence of nutritional status during the autumn months on the timing of puberty in Soay ewes, within the ranges of weight and food intake studied, compared with Suffolk $\times$ Greyface ewe lambs. 

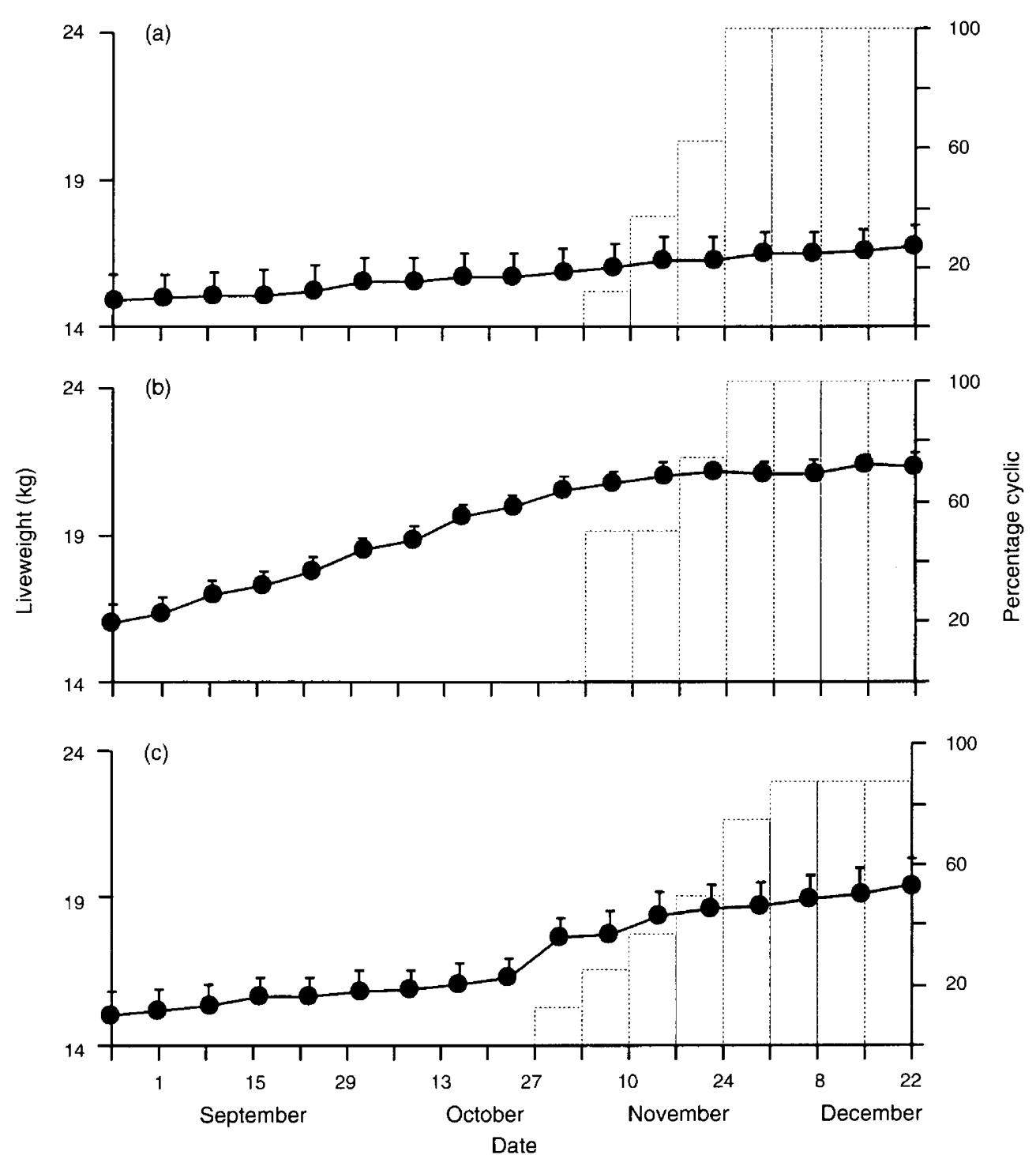

Fig. 3. Mean liveweight and cumulative percentage showing ovarian cyclicity (shaded area) of Soay ewe lambs reared in artificial photoperiod providing a seasonally advanced decrease in daylength and given (a) restricted food intake, (b) ad libitum food intake, or (c) restricted followed by ad libitum intake (Expt 2).

Puberty in the ovariectomized, oestradiol-implanted Soay lambs was indicated by the activation of pulsatile LH secretion, which occurred concomitantly with the initiation of ovulatory cycles in the ovary-intact lambs (Fig. 1b), presumably as a result of reduced sensitivity to oestradiol inhibitory feedback (Foster and Ryan, 1979). Although effects on fertility and conception rate cannot be ruled out, neither low bodyweight nor low food intake prevented or delayed pubertal activation of the GnRH pulse generator. Conversely, early activation of the $\mathrm{GnRH}$ pulse generator was not stimulated by high bodyweight or high nutritional status. In addition, after activation, the frequency of LH pulses was unaffected by nutritional status (Fig. Id).

Pubertal date showed no correlation with liveweight for the Soay ewe lambs in the present study (Fig. 2). Moreover, up to twofold differences in food intake by lambs of similar low liveweight did not affect the timing of puberty (Fig. 2). It could be argued that the nutritional treatments were imposed too late in development or that they were insufficiently extreme to reveal different pubertal responses (for example, compared with the data of Foster et al. (1989) and Suttie et al. (1991)). Nonetheless, by contrast, the timing of puberty in the present Suffolk-cross ewe lambs was affected by similar nutritional treatments, imposed similarly over the 11 week period preceding normal puberty (which was determined as the pubertal date for lambs fed ad libitum). For the food-restricted Soays (Expt I: Group OVXR, and Expt 2: Group PR) mean pubertal liveweight averaged $76 \%$ that of their ad libitum-fed counterparts, and puberty occurred on the same date within each experiment for both groups. However, the food-restricted Suffolk-cross lambs (Expt 3: Group CR) averaged a similar $73 \%$ of the pubertal liveweight of their ad libitum-fed counterparts, yet their puberty was delayed by at least 2 weeks (it is unlikely to have been delayed indefinitely, given the follicular activity seen in the ovaries, and in view of the greater severity of restriction 

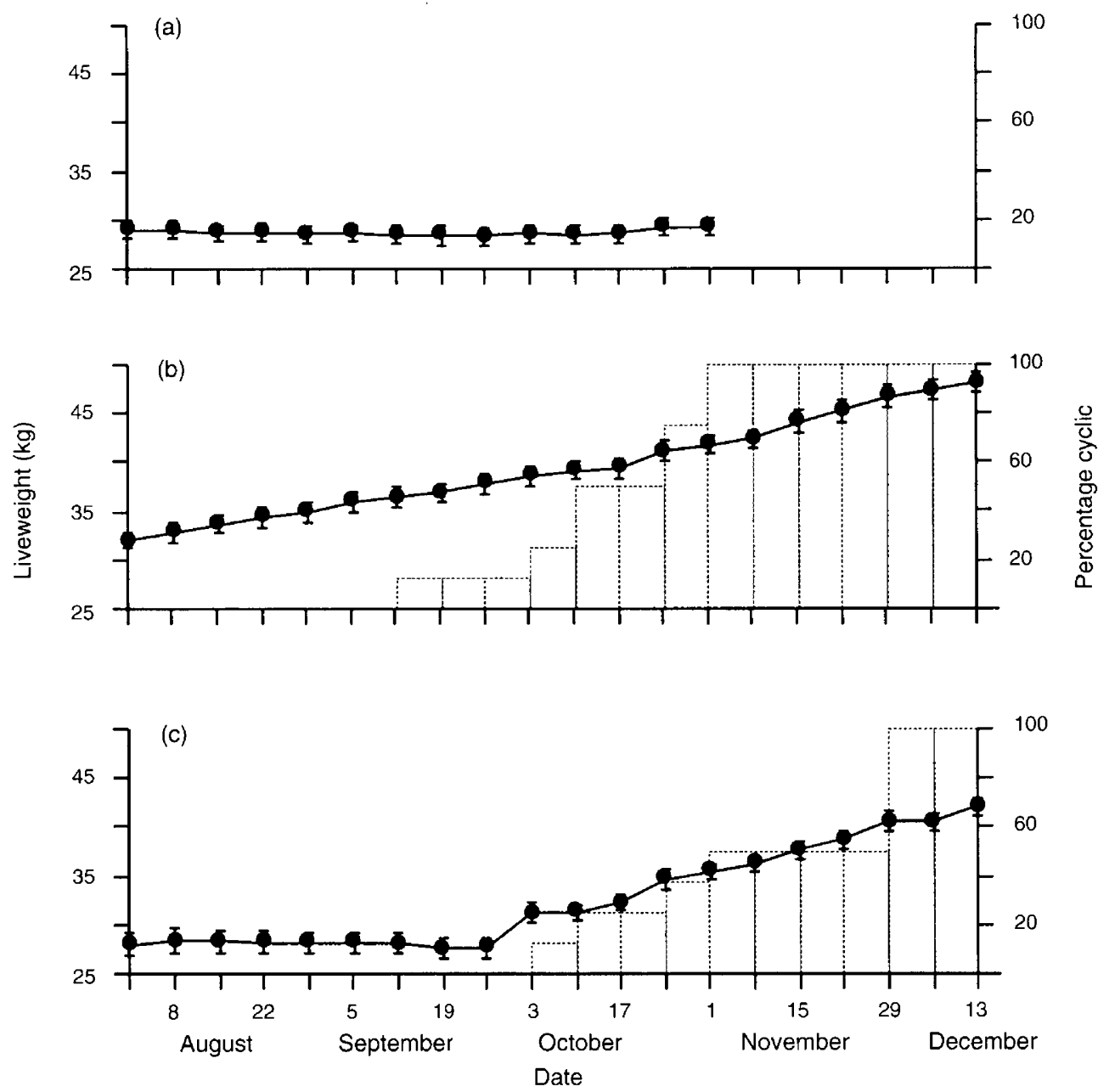

Fig. 4. Mean liveweight and cumulative percentage showing ovarian cyclicity (shaded area) of Suffolk $\times$ Greyface ewe lambs given (a) restricted food intake, (b) ad libitum food intake, or (c) restricted followed by ad libitum intake (Expt 3).

required to prevent puberty in the ewe lambs of Foster $e t$ al. (1989) and Suttie et al. (1991)).

Puberty occurred at liveweights varying by $100 \%$ for Soay ewes $(13.0-26.0 \mathrm{~kg})$ but over a smaller range of $44 \%(31.0-$ $44.5 \mathrm{~kg}$ ) for the Suffolk-cross lambs. A reduction of up to $50 \%$ in liveweight of the Soays (below that attained on feeding ad libitum) did not alter the timing of puberty, whereas a reduction of $33-42 \%$ in the Suffolk-cross lambs did delay pubertal ovulation. A less extreme $7-20 \%$ reduction in liveweight of commercial Coopworth lambs below their normal weight for puberty was also associated with a significant delay (Suttie et al., 1991). In addition, increased food intake at low liveweights advanced puberty in the Suffolk-cross lambs (Group CR/F compared with Group CR) but not in the Soays (Group PR/F compared with Group PR). Although the present results cannot exclude the possibility that more severe undernutrition may have prevented puberty in the Soay ewes, nonetheless, they indicate that its timing was less sensitive to nutritional manipulation during the 11 week period leading up to normal puberty than in the commercial Suffolk-cross ewe.

In agreement with previous reports (Jewell and Grubb, 1974; Lincoln and Short, 1980), breeding activity in the female Soays in natural photoperiod started late in the year (NovemberDecember). Therefore, with unrestricted food, their age at puberty was greater ( 32 weeks) than in the Suffolk-cross lambs (27 weeks) which ovulated in October. This was not attributable to the lower growth rate of the Soays since puberty was not attained in the group fed ad libitum when they had grown to the pubertal liveweight of the restricted group several weeks earlier. Rather, the improved Suffolk-cross lambs (selected over the years for early breeding, among other traits) apparently perceived permissive photoperiod earlier in the year than did the unimproved, unselected Soays. Thus, nutritional factors were ultimately timing puberty in the Suffolk-cross lambs, permissive photoperiod having already been experienced, but photoperiod was ultimately timing puberty in the Soays, for which permissive nutritional status had already been experienced. The occurrence of puberty on the same calendar date across all groups within each of Expts 1 and 2, and some 3 weeks earlier in the seasonally advanced photoperiodic environment of Expt 2 than in the natural photoperiod of Expt 1 , lend support to the presumption that photoperiod is the dominant cue timing puberty in the Soays. 'Photoadvancement' did not alter the insensitivity of pubertal date to 
nutritional status, but liveweights at puberty tended to be lower in Expt 2, commensurate with the younger age of the lambs. Whereas strict seasonality is not a prerequisite for domestic breeds of sheep to rear their offspring successfully on the farm, early breeding in response to improved nutrient status for the feral Soay would carry an unacceptable risk of early births before seasonal weather and food supplies are adequate for survival of the offspring. Adapted to life in a harsh natural environment, it is evidently advantageous for the Soay to retain its strict breeding photosensitivity.

An alternative explanation for the lack of treatment effect in the Soays is the possibility that female-to-female pheromonal communication effectively synchronized the groups (Zarco et al., 1995). However, the Suffolk $\times$ Greyface lambs, kept in similar conditions, showed no evidence of this phenomenon. This could represent another breed difference but does not affect the result that the timing of puberty, whatever the trigger, was not modified by nutritional status in Soays in the present study.

It is generally accepted that both internal (growth and nutrition) and external (photoperiod) cues time puberty in female sheep (Foster et al., 1985; Adam and Robinson, 1994) and that photoperiod is the primary determinant in wellnourished, rapidly-growing lambs, whereas undernourished lambs cannot respond to stimulatory photoperiod, as confirmed by the commercial ewe lambs in the present study. However, within the weight range and period of restriction studied, neither bodyweight nor food intake influenced the timing of puberty in the Soay ewe lambs. This does not preclude the possibility that a more severe weight restriction may have influenced the timing of Soay puberty. Nevertheless, the present data raise the intriguing prospect that there may be significant breed differences in the relative importance of nutritional versus photoperiodic mechanisms timing ovine puberty, particularly between improved and unimproved breeds.

The authors thank J. M. Wallace (Rowett Research Institute) for carrying out the ovariectomies and for the gift of progesterone antiserum, F. E. Gebbie (Scottish Agricultural College, Aberdeen) for carrying out the oestradiol determinations, M. B. Brown (University of Michigan) for permission to use PulseFit software, and the staff of the Duthie Farm for the daily care of the animals. This research was funded by the Scottish Office Agriculture, Environment and Fisheries Department.

\section{References}

Adam CL and Robinson JJ (1994) The role of nutrition and photoperiod in the timing of puberty Proceedings of the Nutrition Society 53 89-102

Adam CL, Kyle CE and Young P (1994) Influence of prenatal photoperiod on postnatal reproductive development in male red deer (Cervus elaphus) Journal of Reproduction and Fertility 100 607-611

Djahanbahkch O. Swanston IA, Corrie JET and McNeilly AS (1981) Prediction of ovulation by progesterone Lancet ii 1164-1165

Foster DL and Olster DH (1985) Effect of restricted nutrition on puberty in the lamb: patterns of tonic luteinizing hormone (LH) secretion and competency of the LH surge system Endocrinology 116 375-381

Foster DL and Ryan KD (1979) Endocrine mechanisms governing transition into adulthood: a marked decrease in inhibitory feedback action of estradiol on tonic secretion of luteinizing hormone in the lamb during puberty Endocrinology 105 896-904

Foster DL, Yellon SM and Olster DH (1985) Internal and external determinants of the timing of puberty in the female Journal of Reproduction and Fertility $\mathbf{7 5}$ $327-344$

Foster DL, Ebling FJP, Micka AF, Vannerson LA, Bucholtz DC, Wood RI, Suttie JM and Fenner DE (1989) Metabolic interfaces between growth and reproduction. I. Nutritional modulation of gonadotropin, prolactin, and growth hormone secretion in the growth-limited female lamb Endocrinology $\mathbf{1 2 5}$ $342-350$

Jewell PA and Grubb P (1974) The breeding cycle, the onset of oestrus and conception in Soay sheep. In Island Survivors pp 224-241 Eds PA Jewell, $C$ Milner and J Morton Boyd. Oxford University Press, London and New York

Karsch FJ, Dierschke DJ, Weick RF, Yamaji T, Hotchkiss J and Knobil E (1973) Positive and negative feedback control by estrogen of luteinizing hormone secretion in the rhesus monkey Endocrinology 92 799-804

Lincoln GA and Baker BI (1995) Seasonal and photoperiod-induced changes in the secretion of $\alpha$-melanocyte stimulating hormone in Soay sheep: temporal relationships with changes in $\beta$-endorphin, prolactin, follicle-stimulating hormone, activity of the gonads and growth of wool and horns Journal of Endocrinology 144 471-48I

Lincoln GA and Short RV (1980) Seasonal breeding: nature's contraceptive Recent Progress in Hormone Research 36 I-5I

Loeber JG, van de Wiel DFM and Gaines Das RE (1987) An international collaborative study on the First International Standard of bovine luteinizing hormone for immunoassay journal of Reproduction and Fertility $\mathbf{7 9}$ $145-152$

Mann GE, Lamming GE and Fray MD (1995) Plasma oestradiol and progesterone during early pregnancy in the cow and the effects of treatment with buserelin Animal Reproduction Science 37 121-131

Suttie JM, Foster DL, Veenvliet BA, Manley TR and Corson ID (1991) Influence of food intake but independence of body weight on puberty in female sheep Journal of Reproduction and Fertility 92 33-39

Zarco L, Rodriguez EF, Angulo MRB and Valencia J (1995) Female to female stimulation of ovarian activity in the ewe Animal Reproduction Science 39 $251-258$ 